\title{
ENTREVISTA \\ Entre os dois lados do Reno: uma entrevista com Peter Dews*
}

\author{
Talita Cavaignac e Thomas Amorim \\ talitacavaignac@usp.br e thomasamorim@usp.br \\ (Doutoranda em filosofia pela Universidade de São Paulo e doutorando em \\ sociologia pela Universidade de São Paulo, São Paulo, Brasil)
}

Peter Dews é professor emérito de Filosofia da Universidade de Essex. Nascido em 1952, estudou Filosofia, Sociologia e Literatura. Passou por universidades diversas como professor visitante, dentre as quais a New School for Social Research, da Universidade de Columbia, Nova York. Seus principais campos de interesse são o pensamento francês contemporâneo, a Escola de Frankfurt e o idealismo alemão. Além de inúmeros artigos, destacou-se pela publicação de Logics of Disintegration (1987), The Limits of Disenchantment (1995) e The Idea of Evil (2008). Foi também editor de Autonomy and Solidarity: Interviews with Jürgen Habermas (1986) e coeditor de Deconstructive Subjectivities (1996). Para o Brasil, tem artigos diversos traduzidos: "Adorno, pós-estruturalismo e a crítica da identidade" (1996), "O eclipse da coincidência" (2005), "O problema do mal após Freud" (2008) e "A verdade do sujeito: linguagem, validade e transcendência em Lacan e Habermas” (2013). Agradecemos a gentileza pela concessão da entrevista.

Professor, você poderia nos contar um pouco sobre sua experiência e como veio a estudar filosofia?

Peter Dews: Sou um exemplo clássico da mobilidade social britânica do pós-guerra. Nasci em 1952 e cresci em uma família da classe trabalhadora. Vivíamos em um subúrbio de casas recém-construídas nos arredores de Birmingham. Aos onze anos, ganhei uma bolsa de estudos para a King Edward's School, Edgbaston, a escola academicamente mais prestigiada da cidade. A escola estava repleta de esnobismo social, o que era doloroso para um adolescente da minha família, mas abria as janelas

\footnotetext{
* Entrevista concedida em janeiro de 2017 em São Paulo. Publicada originalmente, com modificações, na New Left Review, London, 112, julho-agosto 2018, pp.99-129, com o título "The Idea of Hope".
} 
para novos mundos intelectual e cultural. Tenho lidado com a ambivalência dessa experiência desde então.

Comecei estudando literatura na Universidade de Cambridge. Era muito bom em inglês quando estava na escola e meu professor favorito me aconselhou a estudar literatura inglesa em Cambridge. Mas isto era no início da década de 1970, um período em que a abordagem da literatura em Cambridge era bastante estreita, ainda à sombra de Leavis e do New Criticism - resumia-se a responder aos textos, sem muita consideração ao contexto histórico ou político da literatura. Um exercício que precisávamos realizar, por exemplo, era datar dentro de uma estimativa de vinte anos uma peça da prosa inglesa sem saber seu autor, com base no vocabulário e características estilísticas. Achava a abordagem bastante insatisfatória. As únicas palestras que me preocupava em participar eram as de Raymond Williams e George Steiner.

Após terminar a graduação quis fazer um tipo de estudo que estivesse mais conectado com política, sociologia e também filosofia. Suponho que esses interesses teóricos eram inseparáveis do meu interesse pelo que estava ocorrendo no mundo, particularmente a Revolução Cubana, a guerra do Vietnã e as lutas anticoloniais. Eu havia seguido como estudante os eventos de maio parisienses - lembro de ler lido Daniel Cohn-Bendit, Comunismo Obsoleto: a alternativa da esquerda - e me envolvi brevemente com alguns estudantes radicais da Universidade de Birmingham, panfletando, exibindo filmes anti-imperialistas, esse tipo de coisa. Em 1975, após dois anos de empregos provisórios e de passagens pela América Central e do Norte, fui para a Universidade de Essex, onde ensino agora, e fiz um mestrado em Sociologia da Literatura. Acredito que já pensei nisto como uma ponte para a filosofia, que era, no fundo, o que eu realmente queria.

O metrado em Sociologia da Literatura em Essex foi um dos primeiros cursos de mestrado em teoria literária no Reino Unido - possivelmente o primeiro. Lemos muito teoria literária marxista, autores como Lukács e Lucien Goldmann, mas também Saussure, Barthes e um pouco de Derrida, que estava apenas começando a se tornar conhecido naquela época. Nossos professores incluíram Gabriel Pearson, que esteve envolvido com a New Left Review nos anos iniciais, e Stanley Mitchell, o tradutor e acadêmico itinerante, que foi o primeiro professor em russo da universidade. Ele também escreveu para a New Left Review nos protestos estudantis de 1968 em Essex. No final de sua vida, ele publicou uma tradução maravilhosa de Eugene Onegin. 0 que realmente me entusiasmou durante o trabalho para o mestrado foram a teoria literária e filosofia francesas, decidindo que gostaria de escrever uma tese de doutorado sobre Derrida. No entanto, estava determinado a fazer minha pesquisa em Derrida em um departamento de filosofia, algo que era basicamente impensável àquela época. Por sorte, consegui encontrar um orientador receptivo na Universidade de Southampton. 
O chefe do departamento, Anthony Manser, era um filósofo treinado em Oxford, que desenvolveu um interesse dissidente por pensadores como Sartre e Hegel. Ele publicou um livro sobre Sartre em 1966, o que era uma coisa outré para um filósofo britânico naquele tempo. ${ }^{1}$ Thony deve ter visto algo na minha aplicação, pois ele me arranjou uma bolsa doutoral de três anos da Universidade. À minha chegada, ele não compreendeu realmente o que eu estava fazendo, mas era gentil e me deixou seguir em frente. Quando comecei a pesquisa, precisei aprender por mim mesmo a história da filosofia, uma vez que não era meu campo original. Apenas sentei na biblioteca e comecei a ler Hume, Leibniz, Kant, Wittgenstein. Também tentei me familiarizar com algo da filosofia analítica então influente - Donald Davidson, por exemplo.

No outono de 1977, segundo ano de meu doutorado, fui para Paris e me inscrevi como estudante visitante na universidade "experimental" Paris VIII, que foi criada no rescaldo de Maio de 1968 e então localizada em Bois de Vincennes. Deleuze e Lyotard davam semanalmente aulas e havia um departamento inteiro dedicado à psicanálise lacaniana. Comecei a ler Foucault, Deleuze, Lyotard e Lacan, bem como Derrida, e fiquei interessado na constelação inteira da filosofia francesa conhecida como pós-estruturalismo. Mas também sempre tive um interesse em teoria social, particularmente, na teoria crítica da Escola de Frankfurt - já então tentando ler $O$ homem Unidimensional como estudante -, e decidi que queria comparar essas duas correntes do pensamento. Minha ideia essencial era que o pós-estruturalismo realmente era um modo de criticar aspectos da modernidade, da subjetividade e das formas modernas da experiência, mas carente da reflexividade sociológica da Escola de Frankfurt. Se considerarmos ambas conjuntamente, poderíamos ler o pósestruturalismo como um tipo de teoria crítica, mas menos autoconsciente que aquela da Escola de Frankfurt. Esta foi a ideia básica do meu doutorado, que se tornou meu primeiro livro, Logics of Disintegration (1987). Foi de fato a primeira comparação sistemática entre o pós-estruturalismo e a Escola de Frankfurt. Naquela época era um paralelo muito inusual para se traçar. Eram duas tradições mutuamente alheias. Pessoas que estavam interessadas em Foucault ou Derrida eram ignorantes - se não antagônicas - à Escola de Frankfurt e vice-versa. 0 doutorado foi então uma tentativa de mostrar que uma possibilidade de diálogo entre essas duas tradições era possível, embora eu não dissimule o fato de que minha simpatia estava afinal do lado da Escola de Frankfurt.

\section{E como foi sua trajetória profissional após sua formação?}

Durante e depois do doutorado, ensinei filosofia em tempo parcial em universidades diversas em Londres por muitos anos. Este período foi o ápice do thatcherismo e as

1 Manser, A. (1966). Sartre: A Philosophic Study. London: Bloomsbury Academic. 
publicações universitárias na filosofia eram poucas e distantes entre si. Em 1986, graças à iniciativa de alguém que se tornou um amigo fixo, Andrew Bowie, consegui uma posição temporária de dois anos no que é agora a Universidade Anglia Ruskin em Cambridge, ensinando em um curso de graduação incomum chamado "Pensamento Europeu e Literatura”. Estávamos loucamente sobrecarregados. Eu corria de um seminário de Balzac ou Flaubert para outro sobre os Pensées de Pascal ou a Genealogia da Moral de Nietzsche e depois para uma discussão sobre a Mãe Coragem ou A Casa de Bernarda Alba. Dois anos depois, consegui finalmente um emprego permanente na Universidade de Essex. Talvez fosse o único departamento de filosofia que poderia ter me aceito. Naquela época a filosofia britânica era dominada pela filosofia analítica o que ainda é muito o caso. Essex era uma exceção. Desde sua fundação, em meados dos anos 1970, teve uma trajetória diferente. O professor fundador, um americano chamado Frank Cioffi, foi um professor excêntrico e carismático que não publicava tanto - um estudioso de Wittgenstein obcecado por criticar Freud. Mas talvez devamos à sua excentricidade que ele estivesse determinado a começar um tipo diferente de departamento, abrangendo tradições diversas da filosofia continental europeia, bem como a passagem analítica tradicional. Ainda assim, eu era um candidato incomum. Minha primeira graduação foi em literatura e eu não havia sido qualificado na tradição analítica mainstream. De certo modo tive sorte em conseguir o emprego. Essex foi o lugar certo para mim - uma afinidade eletiva.

\section{Que direções seu trabalho tomou desde então?}

Quando comecei a trabalhar lá, me interessei cada vez mais pelo idealismo alemão, embora já tivesse entrado em contato brevemente com Fichte, Schelling e Hegel em Logics of Disintegration. Eu acreditava que deveríamos retornar a Kant e à explosão intelectual que conhecemos como idealismo alemão, para compreender os problemas básicos e orientação do pensamento europeu continental recente. Estava formando a visão que muito da recepção da filosofia francesa contemporânea, então em plena marcha na Inglaterra e Estados Unidos, era ingênua, devido a uma carência de interesse naquelas raízes. Uma das minhas principais questões desde então tem sido conectar desenvolvimentos modernos ou contemporâneos nas filosofias francesa e alemã a seus precursores no pensamento pós-kantiano. Muitos dos ensaios em meu segundo livro, The Limits of Disenchantment (1995), fazem essas conexões entre o pensamento europeu contemporâneo e o idealismo alemão.

Meu terceiro livro, The Idea of Evil (2008), foi um pouco ponto de partida. Ainda estava fazendo algo similar, no sentido de que começo com Kant, Schelling, Fichte e Hegel e traço a problemática do mal através desses pensadores e depois Nietzsche e Schopenhauer, terminando com Levinas e Adorno. Talvez o título do livro 
não seja muito conveniente, porque quando se pensa sobre o problema do mal temse em vista geralmente a questão da teodiceia. Como justificar ou acreditar em Deus tendo em vista todo o mal e sofrimento no mundo? Eu comecei com um problema bastante diverso. Se você olhar para a história da filosofia e do pensamento político, pessoas pessimistas sobre a natureza humana tendem a ser de direita, enquanto pensadores de esquerda tendem a ser otimistas - com frequência, a meu ver, excessiva ou ingenuamente. Quis interromper esse alinhamento. Eu estava interessado em pensadores com preocupações progressistas - que acreditavam, em última instância no poder da razão, se se quiser assim dizer -, mas que não eram naïfs sobre o tipo de mal que os seres humanos são capazes. Esta foi a tensão filosófica central ao redor da qual girou o livro. Schopenhauer e Nietzsche auxiliaram como contraexemplos: eles levantam a questão [sobre] como se pode viver a modernidade se se desiste de qualquer noção de progresso social e moral.

Você apresenta como uma ironia o fato que, para se opor a filosofias centradas em uma consciência totalizante, o pós-estruturalismo regressa à sua própria forma primitiva de totalidade, baseada em uma noção abstrata da diferença. 0 resultado seria uma imersão em fragmentos e perspectivas, uma ontologia ao seu modo tão absoluta quanto a unidade que se pretende combater. Você poderia comentar um pouco sobre essas questões?

Como mencionei, eu estava interessado em ler os pensadores pós-estruturalistas como envolvidos na crítica da modernidade. Talvez o caso de Foucault seja o mais óbvio, ele foi o mais diretamente político e histórico-sociológico daqueles pensadores. Em certo sentido, eu era simpático à crítica do sujeito desenvolvida pelo pós-estruturalismo, mas já muito cedo li a Dialética Negativa de Adorno, que ainda quase ninguém havia lido naquele tempo. Percebi imediatamente semelhanças muito estreitas entre os dois modos de pensar. Escrevi sobre isso no primeiro capítulo de Logics of Disintegration. Esses paralelos foram também a base para meu ensaio “Adorno, Pós-Estruturalismo e Crítica da Identidade"2, que escrevi em um dia em um lapso de inspiração.

Para simplificar, concluí que a crítica pós-estruturalista do sujeito era não dialética da perspectiva de Adorno. Como expressão da desilusão, havia uma crítica válida da rigidez de uma subjetividade burguesa do automonitoramento, mas ela não tinha alternativa a oferecer. Tudo que se propôs foi uma desintegração, uma dispersão da subjetividade, não abrindo, portanto, qualquer tipo de perspectiva política progressista. Esta é uma razão central porque sempre tive reservas ao pós-

2 Dews, P. (1986). Adorno, Post-Structuralism and the Critique of Identity. New Left Review, I/157, mai.-jun. (Ed. bras.: Dews, P. (1996). "Adorno, Pós-Estruturalismo e Crítica da Identidade". In: Žižek, S. [org.]. Um mapa da ideologia. Rio de Janeiro: Contraponto, 1996). 
estruturalismo, embora também mantendo certa simpatia - por sua urgência em quebrar padrões rígidos de pensamento, em constranger concepções de identidade, o que considerava como potencialmente emancipatório.

Se olharmos para a história da recepção do pós-estruturalismo, ele foi em parte uma reação contra o marxismo, particularmente na Grã-Bretanha, onde Althusser e o marxismo althusseriano haviam sido bastante influentes por um momento, certamente muito mais influente que a Escola de Frankfurt. Não muitos liam a Escola de Frankfurt, mas muita gente estava interessada em Althusser e nos pensadores estruturalistas como Lévi-Strauss. Um fator a se considerar é que as pessoas britânicas mais formadas, se têm uma segunda língua, falam francês em vez de alemão. Então, para alguns, a mudança para Foucault e seus colegas parecia um próximo passo óbvio. 0 pós-estruturalismo parecia uma radicalização do estruturalismo - você poderia ter o mesmo antissubjetivismo ou "anti-humanismo", sem o constrangimento de exigências enfadonhas quanto à cientificidade (Althusser promoveu na mente de muitas pessoas a ligação entre Marx e sua própria concepção idiossincrática de cientificidade). Mas, como deixei claro, sempre tive reservas sobre o caráter não dialético e as implicações políticas do pós-estruturalismo.

Você aprecia em Logics of Disintegration a análise da "lógica da destruição" - $e$ suas consequências ambivalentes - sustentada pela crítica da identidade de Adorno. Mas você vê como uma limitação em seu pensamento a carência de um componente intersubjetivo, que teria se efetivado de maneiras diversas por autores como Lacan e Habermas. Como você avalia hoje as demandas de uma teoria que leve em conta os problemas da intersubjetividade sem negligenciar a crítica da ideologia e da reificação como a efetuada pela primeira geração da Escola de Frankfurt?

É muito comum as pessoas estabelecerem um tipo de conflito entre a geração pós1930 da Escola de Frankfurt e a segunda geração, conduzida por Habermas - e talvez também a terceira, exemplificada por Axel Honneth. Sempre fui resistente a esse modo de pensar, em que se deveria apoiar ou Adorno ou Habermas e haveria um conflito profundo entre essas duas maneiras de pensar. Sempre fui interessado na tradição de Frankfurt como um todo, mais empenhado em enfatizar as continuidades, ao invés de acreditar que há um tipo de divisão rígida entre a primeira e segunda gerações.

Estou inclinado a pensar que há uma espécie de cegueira sobre a intersubjetividade na primeira geração da Escola de Frankfurt. Autores como Habermas e Honneth estavam certos em dizer que Adorno ainda pensava em termos de um modelo sujeito-objeto. Pode-se argumentar que com conceitos como mímesis Adorno estava tentando pensar sobre a intersubjetividade, sobre relações de empatia 
e reciprocidade entre seres humanos, mas ele não tem um acervo explícito de categorias para tanto. Sua tendência é sugerir que a sociedade se tornou tão reificada e objetificada que seria inocente depositar quaisquer esperanças na dinâmica e no potencial de relações intersubjetivas. Concordo então que há um problema com Adorno a esse respeito. Habermas estava certo em sugerir a existência de uma dinâmica de democratização construída na modernidade, a qual os pensadores da primeira geração, em parte por sua experiência do fascismo e totalitarismo, não apreciaram realmente. Por outro lado, pensadores posteriores da Escola de Frankfurt, que puseram tanta ênfase na intersubjetividade e no potencial democrático de relações intersubjetivas, se tornaram muito complacentes e essencialmente socialdemocratas em suas perspectivas. Existem pontos fortes e fragilidades de ambos os lados. Após 30 ou 40 anos de neoliberalismo e do impacto que isso teve nas estruturas e processos democráticos, podemos ver agora que o fato de que precisamos de categorias para pensar sobre a intersubjetividade deve se distinguir de uma confiança questionável na proteção oferecida pela democratização contra as forças do mercado, considerado como parte do avanço garantido do que Hegel chamou "razão efetiva".

Nesse sentido, penso frequentemente que a teoria da reificação e da razão instrumental de Adorno é uma descrição muito boa do mundo contemporâneo, em alguns aspectos bem melhor que a consideração de Habermas. Uma objeção feita a Adorno é que ele às vezes fala sobre uma concatenação total da ilusão, ou remete à sociedade administrada de modo muito totalizante. Minha sugestão seria ler tal discurso como um exagero para efeito retórico, como puxar o cordão do alarme. Não precisamos levar isto literalmente, mas ele certamente iluminou tendências muito fundamentais na sociedade capitalista contemporânea, que foram apenas reforçadas sob o neoliberalismo.

Você reexaminou a divisão tradicional entre as diversas gerações da Escola de Frankfurt. Mas você não acha que as posições frente aos limites da sociedade capitalista são bastante distintas nas diversas gerações?

Entendo o que vocês querem dizer. É uma questão complicada. Por exemplo, o jovem Habermas, dos anos 1950, 1960, até meados dos anos 1970, era ainda bastante marxista em sua perspectiva. Seria possível mesmo, em alguns aspectos, inverter o conhecimento recebido sobre essa questão. Por exemplo, em meados dos anos 1970 Habermas publicou uma coletânea de ensaios intitulada Para a reconstrução do materialismo histórico. ${ }^{3}$ Poder-se-ia dizer que Habermas fez uma tentativa muito mais séria para reconstruir uma teoria marxista da história que Adorno. Seria possível

3 Habermas, J. (2016). Zur Rekonstruktion des historischen Materialismus. Frankfurt am Main: Suhrkamp. (Ed. bras.: Para a reconstrução do materialismo histórico. Tradução de Rúrion Melo. São Paulo: Unesp, 2016). 
questionar: "o que Adorno e Horkheimer dizem na Dialética do Esclarecimento é realmente uma contribuição para uma teoria marxista da história?”. Eles parecem rastrear problemas da razão instrumental e reificação muito além do capitalismo. A Dialética do Esclarecimento não é realmente uma teoria do capitalismo, mas da dominação da razão instrumental no conjunto da história humana.

De novo, acho que existem aspectos fortes e fracos em ambos os lados. À luz dos desenvolvimentos do capitalismo no período passado, podemos ver que Habermas foi excessivamente otimista sobre os potenciais da democracia liberal. Em seu cenário preferido, impulsos inovadores decorrentes da sociedade civil deveriam pressionar a política institucionalizada e orientar os processos parlamentares de formação da vontade democrática. Acredito que ele agora admitiria que as coisas não estão avançando desta forma, que a democracia liberal está sendo corroída pelas forças da economia capitalista global. Infelizmente, ele não tem uma resposta para esses problemas dentro do imenso edifício teórico que ele construiu mais do que Hegel sabia o que fazer com a "subclasse" dentro da ordem econômica e política supostamente racional retratada na Filosofia do Direito. Leio o elogio recente de Habermas a Emmanuel Macron, como suposto campeão da solidariedade transnacional dentro da União Europeia e, por conseguinte, como defensor de um "modelo social" europeu espectral, mais como sinal de desânimo do que qualquer outra coisa. ${ }^{4}$ Talvez precisemos dizer que, por um período após a Segunda Guerra, não era irracional pensar que o capitalismo poderia ser domado pela socialdemocracia. Mas a noção de que o objetivo subjacente da União Europeia era reforçar essa tendência já exigia um ato de fé. Adorno nunca acreditou realmente no potencial da socialdemocracia ou sempre foi apreensivo. Então talvez a história tenha reivindicado Adorno ao invés de Habermas. Para dar apenas um exemplo, Adorno previu claramente a fusão entre política e entretenimento - e a subjugação do entretenimento pela publicidade. Os escândalos atuais em torno do Facebook e a captação de dados pessoais para campanhas clandestinas de propaganda psicologicamente direcionada não o teriam surpreendido nem um pouco.

Você poderia comentar um pouco sobre a recepção do pós-estruturalismo francês nos países anglófonos?

Estava muito relacionada, acredito, ao surgimento dos novos movimentos sociais, das políticas de identidade. Nos Estados Unidos, ainda mais que na Grã-Bretanha, pensadores como Foucault e Derrida foram vistos como quem fornece os recursos teóricos “naturais”, por assim dizer, para pensar através da fluidez crescente da identidade social e do caráter dos novos movimentos sociais fora do conflito tradicional

4 Habermas, J. (2018). Are We Still Good Europeans?. Zeit Online, 6 jul. 2018; cf. também "Habermas: 'ce fascinant Monsieur Macron”. Les débats de l'Obs, 26 out. 2017. 
entre capital e trabalho. Havia certa dimensão pós-marxista ou antimarxista para esse pensamento também, por exemplo no trabalho posterior de Ernesto Laclau.

Havia certa lógica para esse desenvolvimento e, de fato, o pós-estruturalismo desenvolveu-se de uma maneira muito mais política no mundo anglófono do que na própria França. Por exemplo, quando Derrida começou a ir aos Estados Unidos, era esperado que ele fizesse pronunciamentos políticos. Ele foi compelido a começar a fazer mais afirmações políticas, acredito devido à maneira como sua filosofia havia sido abordada no mundo inglês. Ele começou a escrever então sobre racismo, Nelson Mandela, armas nucleares, a noção de “Estados delinquentes” [États voyous] - notase imediatamente se você olha a bibliografia de Derrida. Para ser honesto, não acredito que esta mudança encorajou seu melhor trabalho. Para o bem ou para o mal, desconstrução não é somente uma forma de crítica - e as coisas começam a dar errado quando o próprio Derrida parece disposto a apagar a distinção, como ele faz em Espectros de Marx. Pessoalmente, prefiro o Derrida inicial, estimulante - mesmo potencialmente niilista - à sua posterior adesão ostensiva ao "ideal emancipatório clássico" ou sua conversa numinosa sobre o infinitamente outro: pelo menos há um desafio. ${ }^{5}$ Como Lacan disse uma vez em algum lugar “não use 'o Outro' como enxaguante bucal [mouthwash]"6. Minha principal preocupação, no entanto, era que havia elementos importantes do marxismo que foram esquecidos nesta fusão do pós-estruturalismo e das políticas de identidade. Acredito que podemos ver isso em retrospectiva.

Um dos desenvolvimentos surpreendentes nos Estados Unidos e Reino Unido foi uma escalada do interesse em Adorno, em conjunto com o declínio do pósestruturalismo. Acho isto intrigante, porque quando escrevi meu primeiro livro, como expliquei antes, Adorno permanecia não lido nas prateleiras. Senti que Adorno teve muitos dos insights e intuições dos pós-estruturalistas, mas os expressou em um modo mais dialético - em outras palavras, não puramente reativo -, sem nunca ter esquecido do problema social e histórico do capitalismo. Este movimento, em certo sentido, quase um movimento do pós-estruturalismo a Adorno, é curiosamente reminiscente do que eu estava pensando no início da minha carreira. É difícil para mim evitar ver isso como um tipo de confirmação. É impressionante o modo como Adorno tornou-se uma figura central nos últimos 10, 15 anos, considerando que nas décadas de 1960 e 1970 quase ninguém o lia no mundo da língua inglesa, ele era quase completamente desconhecido.

\footnotetext{
5 Ver respectivamente: Derrida, J. (2006). Specters of Marx: the state of the Debt, the Work of Mourning and the New International. London: Routledge, p. 112 (ed. bras.: Derrida, J. (1994). Espectros de Marx: o Estado da Dívida, o trabalho do Luto e a Nova Internacional. Tradução de Ana Maria Skinner. Rio de Janeiro: Relume-Dumará); Derrida, J. (1990). Force of Law: The "Mhystical Founfation of Authority". Cardozo Law Review, 11(5-6), julho-agosto, p.971.

6 A edição brasileira traduz como: "O outro - não se deleitem com este termo" (Lacan, J. (1985). Seminário. Livro 2. O eu na teoria de Freud e na técnica da psicanálise. Rio de Janeiro: Zahar, p. 15).
} 
Temos duas questões sobre isso. Como você acredita que seu trabalho possa ter contribuído para o estabelecimento de relações de Adorno ao pós-estruturalismo? Em segundo lugar, você tem uma hipótese do motivo pelo qual o pós-estruturalismo teve mais consequências políticas nos Estados Unidos que na própria França?

Não acho que essas duas correntes foram ligadas na mente das pessoas pelo meu trabalho - pelo menos não em um sentido produtivo. Talvez o máximo que alcancei foi suscitar interesse na possibilidade de comparações, mas estas eram de caráter polêmico. 0 Reno também denotou uma barreira mental; como estudante de doutorado, fui duramente atacado em uma das conferências de "Sociologia da Literatura" em Essex, quando dei uma palestra ousando sugerir que Foucault poderia ser visto como um tipo de weberiano. Hoje isso é lugar-comum. Na verdade, não acho que posso mesmo reclamar muito crédito por provocar as polêmicas. A tradução inglesa do Discurso Filosófico da Modernidade de Habermas, com suas análises de Bataille, Foucault, Derrida, veio à tona no mesmo ano que Logics of Disintegration (a versão original em alemão precedeu meu livro em um ano) e realmente colocou lenha na fogueira.

Sobre a segunda questão, acredito que se deve ao fato de que a política de identidade começou realmente nos Estados Unidos. Eu conjecturo que isto tem relação com a profundidade histórica e a gravidade das questões raciais, a fragilidade do trabalho organizado e outros fatores socioculturais, políticos e legais. Não sou capacitado para avaliar. Obviamente, a Grã-Bretanha e muitos outros países tiveram seu próprio desenvolvimento autóctone - em primeiro lugar, os feminismos que emergiram dos movimentos estudantis de protesto no final dos anos 1960. Mas é certamente o caso que os movimentos de protesto britânicos tiveram uma tendência, nem sempre benéfica, de tomar a deixa dos EUA - dois exemplos recentes são Black Lives Matter e o movimento \#MeToo. Esse não é sempre o caso com a França, onde a diferença de linguagem não permite tão prontamente o que é frequentemente a ilusão de uma cultura compartilhada de protesto. A isso você deve acrescentar o fato de que a filosofia - mesmo a filosofia de vanguarda - tem um tipo específico de dignidade dentro da cultura francesa. Há uma resistência em operacionalizá-la politicamente de uma maneira muito crua ou gritante.

Você é crítico em relação à abordagem pós-estruturalista sobre as questões da identidade e não-identidade, porque, de certa forma, ela obscurece o processo histórico de repressão do não-idêntico. Em que medida você vê esse estilo de filosofia como um resultado ideológico do mundo contemporâneo ou, antes, como potencialmente crítica ao presente?

Isto levanta outro aspecto da recepção do pós-estruturalismo, do qual não falamos 
realmente até agora, a ambivalência. Está conectado às ambivalências da herança da revolução cultural dos anos 1960, poderíamos dizer, e o modo como essas novas concepções mais fluidas e individualizadas da identidade poderiam ser também muito vantajosas ao neoliberalismo. Isto foi uma ambiguidade profunda dentro do pós-estruturalismo, que ajudou a torná-lo tão popular. Embora ele pareça crítico sob um aspecto, sob outro ângulo você poderia ver essa celebração da diversidade, da pluralização de estilos de vida e assim por diante como um reflexo dos desenvolvimentos neoliberais do capitalismo. Podemos entender então porque ele se tornou tão popular dessa perspectiva.

Em certo sentido, a política de identidade não ameaça de todo o neoliberalismo. Lembro de ter lido um artigo há alguns anos de Jackson Lears na publicação The London Review of Books que começava com a declaração "O crescimento da política de identidade foi uma tragédia necessária". ${ }^{7}$ Foi uma tragédia necessária, Lears prosseguia, porque "ninguém pode negar a legitimidade ou urgência da necessidade sentida pelas mulheres e minorias em ter igualdade nos seus próprios termos, em rejeitar a suposição de que a participação plena na sociedade exigia a aceitação das normas estabelecidas por homens brancos heterossexuais". O problema é que, como resultado, "críticas do poder concentrado, imperial ou plutocrático tornaram-se menos comum. De fato, a preocupação com a identidade racial e de gênero esvaziou a linguagem política...".

Aquela formulação, "necessidade trágica”, ficou na minha mente, uma vez que confirmou o que eu havia experienciado como um dos organizadores, ao longo dos anos 1990, de uma conferência anual de Teoria Crítica em Praga. Apesar da fidelidade à Escola de Frankfurt por parte da maioria dos participantes, que vinham sobretudo dos Estados Unidos e de várias partes da Europa, as pessoas pararam de falar sobre capitalismo e, com poucas exceções, a linguagem dos direitos e da política de identidade pareceu varrer o quadro. 0 conflito básico entre trabalho e capital e toda a dimensão econômica dos problemas sociais - que também, é claro, impactam desproporcionalmente em mulheres e minorias - ficaram quase reprimidos. Não podemos considerar o pós-estruturalismo responsável por essa viragem, mas ele certamente o alimentou.

Claro, desde o trauma financeiro de 2008 e a ascensão subsequente dos populismos de direita a constelação teórico-política vem mudando. A política de identidade está agora sendo repreendida por alguns liberais americanos por provocar a ascensão do trumpismo, enquanto na esquerda a corrente exemplificada por Bernd Stegemann, Sahra Wagenknecht e a [organização] Aufstehen começou a desafiar o que é visto como o conluio do "politicamente correto" e do neoliberalismo. Então os sinais de indicação estão mudando. Acho muito cedo para avaliar o que está 
emergindo.

Quanto a questões relativas à subjetividade, como você distinguiria a subjetividade burguesa clássica de suas formas contemporâneas, no sentido de uma substituição do supereu repressor tradicional pelo "imperativo do prazer"?

Entre os pensadores da primeira geração da Escola de Frankfurt, Marcuse teve uma ideia poderosa que você talvez não encontre tão claramente articulada em Adorno, o conceito de dessublimação repressiva. O pensamento de Marcuse era o de que o imperativo do prazer, de satisfazer a si mesmo no prazer sexual e físico, poderia estar longe de ser emancipatório, mas simplesmente outra forma de controlar e desviar a energia das pessoas. Acredito que foi um conceito muito poderoso e, em certo sentido, você poderia usá-lo para encapsular o que estava equivocado no pósestruturalismo, na medida em que este simplesmente teorizou um tipo de desengano da subjetividade em impulso e espontaneidade, minando qualquer capacidade de agência ou resistência intencional.

Considero a noção de Marcuse ainda hoje muito relevante. Experienciei esse tipo de paradoxo da emancipação mais ou menos no dia a dia na minha universidade na Inglaterra. Há na ideologia da universidade uma ênfase tremenda na igualdade das mulheres e nos direitos de lésbicas e gays, nos direitos de grupos étnicos -questões de importância vital. Há todo um discurso da "igualdade e diversidade"muito penetrante em toda a universidade. Mas, ao mesmo tempo, a organização da universidade está se tornando cada vez mais hierárquica, mais e mais neoliberal, estamos submetidos a mais e mais formas de avaliação, controle e monitoramento. Existe então uma contradição real entre esses dois discursos que avançam simultaneamente. Experienciei isso na universidade, mas acho está ocorrendo em muitas áreas da sociedade e acredito que a Escola de Frankfurt, incluindo Marcuse, teve percepções importantes sobre esse processo.

O que você vê como implicações do pensamento pós-estruturalista no debate acadêmico contemporâneo?

Como já discutimos, acho que o pós-estruturalismo como tal tem estado em declínio por um tempo considerável agora no mundo da língua inglesa. Ele não é mais hegemônico nas ciências humanas. Por exemplo, na teoria cultural houve em alguns setores uma guinada de afastamento das tendências idealistas e construtivistas do pós-estruturalismo em direção a uma ênfase na "materialidade" do objeto. Esta dimensão já está em Adorno, é claro, um pensador que se tornou importante como um tipo de substituição (ou avanço, se você preferir). Mas não esqueça que havia um interesse profundo em aspectos do pós-estruturalismo em Frankfurt. Cristoph 
Menke e, em alguns de seus trabalhos posteriores, seu professor Albrecht Wellmer se engajaram produtivamente com Derrida e levaram a sério suas lições relativas à atração da idealização - de fato Wellmer as direciona contra Habermas. Por muitos anos Axel Honneth e seu círculo foram francamente fascinados por Foucault. Totalizar a antitotalização é uma posição demasiado contraditória para durar por muito tempo, mas os impulsos do pós-estruturalismo poderiam se tornar formas mais construtivas de teorização crítica na forma do que Honneth chama de "condição genealógica" em outros termos, um alerta de não se tornar muito confiante sobre a racionalidade, a carência de determinantes ocultos de nossa própria perspectiva. ${ }^{8}$ Acho que esse desejo de integrar uma variedade de intuições e perspectivas aparentemente conflitantes, incluindo elementos do pensamento francês, enquanto não seja tomada pela ilusão da integração pura, é responsável pela relevância contínua e capacidade de renovação da tradição da Escola de Frankfurt. Olhando à distância, é uma herança da concepção de sistema do idealismo alemão.

Entre os teóricos mais focados na tradição francesa, alguns mudaram sua filiação para Alain Badiou. Badiou é uma figura sintomática porque, sob muitos aspectos, representa um retorno à tradição filosófica clássica. Este já era o caso em certa medida em relação a Deleuze, o último grande pós-estruturalista a invadir as humanidades no mundo anglófono. Deleuze - quando não foi levado por Guattari - foi tanto um metafísico construtivo quanto um celebrador da diferença. Mas Badiou vai ainda mais longe. Ele revive o conceito de sujeito e o conceito de verdade, por exemplo, e os relaciona intimamente. Como Lacan, ele não tolera nenhum nonsense nietzscheano sobre a verdade ser uma ilusão indispensável e assim por diante. A referência a Lacan é fundamental - Badiou o chama em algum lugar "nosso Hegel”. Lacan sempre foi exceção entre os pensadores classificados como "pós-estruturalistas". Foi diferente porque nunca parou de falar sobre o sujeito, nunca tentou eliminar ou dissolver inteiramente essa noção, como acredito que fizeram alguns dos outros pensadores franceses daquele período. Ainda mais, ele teve um interesse profundo na dialética da intersubjetividade ou dialética do reconhecimento, proveniente de Kojève e da interpretação de Hegel de Kojève. Ele não se encaixava realmente no molde dos outros pós-estruturalistas, embora a maior parte dos comentadores no âmbito da língua inglesa não tenha percebido isso naquele momento.

Badiou difere de Lacan, no entanto, para pôr em termos simples, em sua reivindicação de que a subjetividade genuína surge do comprometimento [commitment]. É um tipo de revival de temas existencialistas. Uma de minhas reservas principais em relação a Badiou é que, embora ele oponha a si mesmo, em

8 Honneth, A. (2009). "Reconstructive Social Criticism with a Genealogical Proviso: On the Idea of 'Critique' in the Frankfurt School". In: ory. New York: Columbia University Press. 
muitos aspectos, em relação aos pós-estruturalistas, ele também herda muitas de suas falhas. Então, apesar de falar sobre verdade e eventos da verdade, ele guarda uma noção bastante arbitrária do que constitui um evento da verdade, combinada a uma lista arbitrária de domínios nos quais tais eventos podem ocorrer: arte, ciência, política e amor. Ele simplesmente falha em fornecer as mediações que permitiriam conectar sua consideração abstrata e teórica da inovação radical às ocorrências históricas específicas ou aos contextos sociopolíticos. O resultado é decisionismo e fideísmo. Ele se baseia no prestígio do conceito de verdade, mas, tanto quanto me parece, somente para aplicar uma etiqueta de aprovação a suas próprias preferências. Tratei desses aspectos em mais detalhes em minha resenha de $O$ Ser e o Evento. ${ }^{9}$

Badiou é uma figura profundamente ambivalente. Ele rejeita qualquer palpite do relativismo pós-moderno, mas também quer ver a si mesmo na tradição nobre da vanguarda pós-guerra maîtres à penser. Há algo antiquado - na França diriam ringard - sobre seu modo de pensar. Seu ateísmo militante tem mais em comum com Marquês de Sade que com Nietzsche ou mesmo Sartre. Ao mesmo tempo, seu modelo simplista da política - basicamente, uma vez que você retira o traje de fantasia, ordem versus transgressão da ordem - perpetua algumas das piores tendências do pós-estruturalismo.

Lembrando a noção do estágio do espelho, você gostaria de dizer algo mais a respeito da subjetividade em Lacan?

O interessante sobre Lacan é que ele apresenta um conceito enfático de sujeito, mas que não é completamente autoconsciente ou autocentrado. A autoimagem constituída através da relação do espelho ele chama ego ou equipara ao ego freudiano e vê essa dimensão ou aspecto do sujeito como rígido e pertencente ao domínio do imaginário. Mas ele apresenta então um sujeito diverso, o sujeito do inconsciente, móvel, inquieto, que apenas vem a ser. Os antecedentes, penso eu, são sartreanos - ele está engajado em uma elaboração imensamente sutil da distinção entre o cogito reflexivo e o pré-reflexivo, enriquecidos por uma compreensão psicanalítica da dinâmica da intersubjetividade.

Eu acrescentaria que muitos pós-estruturalistas tiveram uma concepção paródica de como o sujeito foi teorizado em toda a tradição da filosofia moderna. Repetidamente os pós-estruturalistas do mundo anglo-saxão, e mais ainda seus partidários, retrataram seu alvo como o sujeito cartesiano ou a subjetividade autocentrada, inteiramente transparente. Entretanto, se você olha efetivamente para a história da filosofia moderna, há muito poucos pensadores, se algum, que tiveram essa concepção de subjetividade. Na tradição empirista britânica, por

9 Dews, P. (2018). Review of Alain Badiou, Being and Event. Notre Dame Philosophical Review, South Bend, Indiana, fev. 2018. 
exemplo, David Hume sem dúvida não pensa no sujeito nesse sentido: o eu se dissolve em um fluxo de ideias ou impressões. Para Kant o sujeito é inacessível, numenal, o que implica, entre outras coisas, que nós nunca podemos saber se agimos ou não moralmente - nossas próprias motivações são, em última análise, obscuras para nós. E Hegel vê os sujeitos humanos como no interior de um sistema ético e social que os descentra, de modo que eles nunca estão completamente conscientes da dinâmica social a qual pertencem. É, na verdade, muito difícil encontrar algum filósofo que represente esse tipo de sujeito completamente autotransparente, o qual os pósestruturalistas pensavam estar atacando.

No seu livro mais recente, The Idea of Evil, a questão da experiência subjetiva da liberdade e da responsabilidade moral é relacionada ao problema do mal. Como você relacionaria uma fenomenologia da moralidade à crítica da ideologia?

Uma das questões que eu estava interessado aí era a relação entre algo como determinações sociais e responsabilidade individual. Sempre tive a impressão de que, por mais que possamos falar sobre ideologia, sobre determinações históricas e sociais, não podemos abandonar inteiramente a ideia de responsabilidade individual. Talvez este tenha sido um dos problemas do desmantelamento pós-estruturalista do sujeito - tudo foi dissolvido em processos linguísticos ou relações de poder. Isto claramente se tornou um problema para Foucault em certo ponto de seu desenvolvimento. Nos anos 1970, ele formulou a visão do sujeito como completamente constituído por relações de poder - mas então ele descobriu que precisava de um local de reflexão e resistência que fosse mais do que apenas impulso corpóreo. Escrevi um artigo chamado "The Return of the Subject in late Foucault", ${ }^{10}$ no qual tentei mostrar que na fase final de seu pensamento ele foi obrigado a reintroduzir um conceito quase existencialista de sujeito e associou a este noções de liberdade e autoconstituição. Eu ouço um barulho de freios e ranger das engrenagens naquele momento, enquanto os foucaultianos conseguem convencer a si mesmos de que tudo faz parte do plano mestre.

Aqui, de novo, Adorno é muito informativo, porque ele usa algumas vezes uma linguagem que sugere que tudo é determinado. Quando ele fala sobre a sociedade administrada, ele usa a palavra alemã Verblendungszusammenhang, que é normalmente traduzida como "contexto de ilusão" [context of delusion]. Ele usa também a imagem do "feitiço": há um feitiço silencioso que captura a todos - em última análise, mais eficaz que a compulsão material. Não obstante, se você lê a Dialética Negativa com cuidado, ele nunca denega completamente a noção de responsabilidade individual. Assim como Verblendungszusammenhang, que

10 Dews, P. (1989). The Return of the Subject in late Foucault. Radical Philosophy, 51, Spring 1989. 
converto como "contexto de ilusão" [nexus of delusion], ele também usa a palavra Schuldzusammenhang, ou "contexto de culpa" [nexus of guilt]. Algumas vezes as utiliza quase sucessivamente. É como se ele dissesse: “sim, precisamos pensar sobre a ideologia, sobre a compulsão social, mas não podemos abandonar completamente a noção de culpa, de responsabilidade”. Este foi um dos problemas que tentei pensar em The Idea of Evil.

Adorno também é muitoútil quando fala de um sentido de repulsa [revulsion], um sentimento espontâneo, quase corporal, de que algo está errado, que absolutamente não deveria estar ocorrendo. Em tais momentos, ele não está se apoiando em princípios ou regras morais, mas em um tipo de sentimento cru do intolerável. Aqui ele está insistindo em um insight muito valioso, que, mesmo dada a força da ideologia ou ilusão, ou como quer que se chame, as pessoas podem ter tais sentimentos de repugnância moral e de rebelião, os quais emergem de um nível mais profundo do que a consciência. Uma observação que li em um livro de Zygmunt Bauman ${ }^{11}$ sobre o Holocausto sempre ficou em minha mente: durante o período nazista na Alemanha, quando os judeus estavam sendo perseguidos, pessoas de diferentes origens e classes sociais, mulheres e homens, de diferentes níveis educacionais e filiações religiosas, os ajudaram a escapar. Não há um denominador sociológico comum, uma categoria social que explique porque certas pessoas fizeram isso. Parece ter havido algo sobre eles como indivíduos que faz algumas pessoas sentirem que, independentemente de sua classe ou posição social, "apesar do perigo, tenho que ajudar meu vizinho judeu ou a pessoa judia que eu conheço". Isso se encaixa muito à consideração de Adorno do que ele chama de das Hinzutretende, o adendo impulsivo que nos empurra sobre a borda da ação moral.

Ao mesmo tempo, Adorno sabe muito bem que as imputações da responsabilidade moral individual podem facilmente tornar-se punitivas. Vemos que sempre que há um tumulto ou desassossego social - como houve na Grã-Bretanha em 2011 - a imprensa e os políticos de direita negam estridentemente a relevância das condições socioeconômicas, o impacto de suas políticas, enquanto os juízes distribuem sentenças grosseiramente desproporcionais. Não há respostas teóricas nem filosóficas para esse enigma. Afinal de contas, o dilema também vale para o outro lado. Quantas pessoas à esquerda, por exemplo, vão desculpar Harvey Weinstein - ou mesmo muitos infratores menores - por estarem presos na ideologia patriarcal? Mesmo a ideologia crítica, pelo menos na tradição da Escola de Frankfurt, envolve conectar-se ao interesse dos seres humanos em viver em um mundo onde a liberdade de cada um é condição da liberdade de todos, não importa quão profundamente enterrado e distorcido possa estar esse interesse. Não é simplesmente uma questão de substituir um ponto de vista por outro, cognitivamente superior. Evidentemente, é quase impossível acreditar

11 Bauman, Z. (1991). Modernity and the Holocaust. Cambridge: Cornell University Press. 
que exista tal interesse último dentro de cada ser humano. Mas que escolha básica temos, politicamente, exceto tentar eliminar, na medida do possível, as condições em que as pessoas são obrigadas a dizer, juntamente com Brecht em O Círculo de Giz Caucasiano, "Terrível é a tentação de fazer o bem"?

Considerando o que você mencionou sobre Adorno na questão anterior, você acredita que poderíamos pensar em algum tipo de transcendência na Dialética Negativa?

Essa é uma conexão interessante. Sempre fiquei impressionado com o fato de que o capítulo final desse livro é nomeado "Meditações sobre a metafísica", porque na história da filosofia, certamente para alguém como Hegel e mesmo Platão, a dialética é oposta à metafísica, no sentido da especulação sobre assuntos transcendentes. Muitos diriam que Hegel não é um pensador metafísico, no sentido de que a metafísica significa fazer reivindicações transcendentes, reivindicando o que se encontra além do conhecimento objetivo, enquanto a dialética envolve apenas o prosseguimento de uma dinâmica de contradições e resolução imanente das contradições.

Acredito que vocês estão certos, se estão sugerindo que Adorno está tentando dizer algo como, "não importa quão consistente ou lógico possa ser nosso pensamento, sempre deve vir um ponto onde temos uma realização, uma experiência reveladora". Isso pode soar perigosamente místico, mas o que ele quer dizer é que rastrear o desdobramento e a resolução de contradições só pode nos levar até aí, porque a energia da contradição é ela mesma parasitária da compulsão da identidade. Como ele coloca na Dialética Negativa: "Em face da possibilidade concreta da utopia, a dialética é a ontologia do estado falso". ${ }^{12}$ Para obter um vislumbre motivador do estado correto das coisas teríamos de algum modo que transcender a dialética.

No capítulo final, Adorno usa o termo “experiência metafísica” para se referir a esses vislumbres. Ele dá apenas alguns indícios sobre o que quer dizer com o termo. Em meu modo de entender, eu referiria ao seu argumento de que a emancipação do sujeito sempre foi à custa do objeto, sempre foi desenvolvido nos termos da dominação do objeto. Esta não é para ele uma emancipação real. Uma verdadeira emancipação do sujeito, realização humana genuína, também permitiria ao objeto o seu próprio ser. É isso o que significa a experiência metafísica: a subjetividade libertando a si própria, saltando sobre sua própria sombra. Como Adorno coloca, "uma experiência metafísica e uma experiência subjetivamente liberta convergem em humanidade". ${ }^{13}$ Como filósofos, pode nos ser difícil aceitar que a conceituação refinada do pensamento filosófico em si pode se tornar um tipo de barreira a qual temos de tentar olhar além. Acho que é o que Adorno está tentando expressar no

12 Adorno, T. (1973). Negative Dialectics. London: Continuum, p.11 (Ed. bras.: Adorno, T. (2009). Dialética Negativa. Rio de Janeiro: Zahar).

13 Idem, p.397. 
capítulo final.

Você diria que nesse tipo de compreensão do pensamento de Adorno, e também em seu livro, The Idea of Evil, há espaço para um elemento utópico? Como você poderia correlacionar seu livro a um tipo de elemento "esperança"?

Em certo ponto do capítulo final da Dialética Negativa, Adorno diz que o segredo da filosofia de Kant é a impensabilidade do desespero. Isto sempre me impressionou como uma sentença particularmente significativa. 0 que ele quer dizer por impensabilidade (Unausdenkbarkeit) do desespero? Podemos obter uma pista a partir do que ele diz sobre Schopenhauer na mesma parte do livro. Sou da opinião de que Adorno toma muito de Schopenhauer - o que nem sempre é uma conexão popular, dadas as atitudes profundamente reacionárias de Schopenhauer. Mas é difícil negar que a concepção de Adorno de "experiência metafísica", por exemplo, é em parte inspirada pela visão de Schopenhauer da suspensão radical da vontade compulsiva. Schopenhauer, no entanto, totaliza o desespero, totaliza uma visão negativa do mundo. Para Adorno, porém, totalizar o desespero é tão equivocado quanto totalizar o otimismo.

Mas esse argumento só nos dá um equilíbrio, não nos dá qualquer razão para nos inclinarmos em direção à esperança ao invés do desânimo. Aqui estou tentado a dizer que a esperança é algo como uma condição de agência, mas esse é um argumento complicado e contencioso que eu realmente não posso desenvolver aqui. 0 ponto crucial é que a esperança não é a mesma coisa que um cálculo de resultados prováveis. Para alguns, isso pode fazer parecer “irracional” e dispensável. Na minha opinião, isso demonstra - assim como a confiança, outra característica indispensável da vida humana, com a qual, é claro, a esperança está conectada - os limites de uma concepção excessivamente racional de agência.

Em certo sentido, meu livro The Idea of Evil poderia ter sido mais apropriadamente chamado The Idea of Hope, devido à sua questão central sobre a relação entre esperança e agência, em particular a agência voltada para objetivos emancipatórios. Se olharmos a história da humanidade e o que os seres humanos são capazes de fazer uns aos outros, não apenas no passado, mas também no presente, como podemos manter a esperança no futuro? Kant estava profundamente interessado nesse problema, "como sustentamos a esperança, dado tudo que sabemos sobre o mundo e os seres humanos?". Sua resposta foi a teoria do que ele chamou os "postulados da razão prática". Os postulados de Kant ainda são moldados pelo cristianismo, mas, mesmo em um mundo pós-cristão, o problema não desapareceu. A agência moral requer mais do que apenas boas razões comunicáveis, requer um horizonte de significado. Como vamos caracterizar esse horizonte de significado? Quão reduzido isso pode ser, ou secularizado se você quiser, sem desaparecer 
completamente?

Mencionei que The Idea of Evil conclui com uma discussão sobre Levinas e Adorno. Entre seus adeptos, Levinas é frequentemente aclamado por oferecer uma "ética sem teodiceia” - em termos seculares, uma ética que austeramente, e mesmo de modo masoquista, desproveu-se de uma preocupação com um horizonte de significado. Procuro mostrar que isso é simplista, uma má interpretação. Se você olhar com cuidado, verá que Levinas não está menos preocupado com a questão do que Adorno, ambos ainda estão lidando com o legado dos postulados kantianos da razão prática. Mas a esperança, neste contexto, não é como a "fidelidade" de Badiou. Badiou aposta em seus eventos preferidos e, dada sua história maoísta, fez algumas escolhas dúbias. A linha de pensamento que tento recuperar em The Idea of Evil diz respeito às condições de possibilidade do compromisso ético-político em geral.

Como o pós-estruturalismo e a noção de esperança poderiam ser correlacionados? Isto é, uma vez que a ideia de esperança está ligada à noção de "significado", isso poderia ser um limite para o pós-estruturalismo?

Há um grande debate sobre a trajetória filosófica de Derrida. Alguns se referem a uma "virada ética" em seu trabalho. Acho que você teria que localizar isso em algum lugar na década de 1980, quando a referência a Levinas começa a se tornar mais e mais proeminente em seu trabalho e ele começa a fazer afirmações surpreendentes como "Justiça em si, se tal coisa existe, fora ou além da lei, não é desconstrutível. Não mais que a própria desconstrução, se é que existe tal coisa". ${ }^{14}$ Muitos entusiastas de Derrida, se esse não for um termo muito depreciativo, negam que exista qualquer reviravolta com sua implicação de descontinuidade. E é preciso dizer que o próprio Derrida também rejeitou qualquer sugestão de uma tournant éthique [virada ética]. Mas filósofos franceses excepcionais parecem alérgicos a admitir que alguma vez mudaram de opinião sobre qualquer coisa - o contraste com a cultura filosófica anglófona e, na verdade, contemporânea alemã, é impressionante a esse respeito.

Para colocar as cartas na mesa, na minha opinião, é incontestável que alguma mudança dramática de orientação ocorreu no trabalho de Derrida nos anos 1980 . O primeiro Derrida está determinado a mostrar que qualquer estabilização do significado, qualquer limitação do jogo do texto, é baseada em última instância em uma ilusão - ainda que seja uma ilusão transcendental ou estruturalmente inevitável. Isso porque qualquer fundamento final do jogo do texto acabará sendo por ter sido postulado pelo jogo do texto. Até onde posso ver, não há muito que possamos fazer,

14 Derrida, J. (1992). Force of Law. In: Cornell, D; Rosenfeld, M.; Carlson, D. (Eds.). Deconstruction and the Possibility of Justice. New York: Routledge, p. 945. 
de acordo com o Derrida anterior, além de abandonarmos a nós mesmos a esse jogo - pelas razões dadas, certamente não há sentido em tentar encontrar um ponto de orientação fora dele. Mas esse argumento também tem consequências políticas e éticas, pois, pelo mesmo argumento, não pode haver nenhum valor ou princípio moral que seja ele mesmo outra coisa senão contextual. "Il n'y a pas de hors-texte", como Derrida disse em sua famosa formulação.

Mas agora podemos perguntar: o que chamamos de inevitável contextualidade? Certamente, essa afirmação não pode também ser chamada de contextual, pois, nesse caso, a afirmação básica de Derrida se cancelaria, a contextualidade não seria total. Por outro lado, se negarmos que esse fato é contextual, então estamos igualmente admitindo, de uma maneira diferente, que a contextualidade não é total. Essa questão aponta para um dilema. E Derrida tenta resolver isto em seu trabalho posterior, mobilizando explicitamente a noção do "indesconstrutível" ["undesconstructible"], uma noção que não desempenha nenhum papel em geral em seus escritos anteriores. Em outras palavras, se a desconstrução é onipresente - como Derrida afirma ser: não há bolsões de identidade pura -, então a condição de possibilidade de desconstrução não pode ser ela mesma desconstruída. Derrida não deu consideração a essa condição de possibilidade em seus escritos anteriores, ele não achava que precisasse de tal coisa, embora tenhamos acabado de ver que isso sempre esteve implícito. Estava implícito porque Derrida precisava proteger a desconstrução dos paradoxos da autorreferência, então ele poderia usar esses paradoxos para driblar a todos. No entanto, esse é um movimento surpreendente, a evocação aberta do "indesconstrutível", um movimento que você poderia pensar que iria, ao menos, oferecer aos defensores da continuidade do empreendimento de Derrida uma pausa para o pensamento.

A próxima pergunta é: o que torna o "indesconstrutível” - ou o que quer que seja que explique a disseminação da desconstrução - diferente do antigo e desonesto "significado transcendental"? Derrida precisa de uma resposta para essa pergunta e a que ele dá é que o indesconstrutível não é um objeto de conhecimento, nem mesmo do que poderia ser pensado como um tipo especial de conhecimento filosófico. Pelo contrário, é um imperativo, um imperativo incondicional que experimentamos ao sermos envolvidos em contextos em constante mudança, através da consciência de que não podemos permanecer honestamente dentro de qualquer moldura delimitada. Podemos ver como esse argumento poderia assumir um caráter ético no pensamento posterior de Derrida, tal como ele pode propor, por exemplo, que “desconstrução é justiça”. ${ }^{15}$ Qualquer realização concreta e específica da justiça será sempre insuficiente, deixará sempre mais a ser feito. Mas se pudermos perceber que houve um fracasso, uma falha, mesmo uma traição, não podemos ser inteiramente 
determinados pelo jogo das formas finitas, contextuais. Deve haver algum tipo de encontro que dirija nossa insatisfação, com uma transcendência ética - o imperativo absoluto, não-desconstrutível da justiça, por exemplo, por mais estranho que possa parecer.

Vocês podem ver que não estamos tão longe da problemática da esperança, como Adorno a desenvolve no capítulo final da Dialética Negativa. De fato, como vocês sabem, Derrida usa uma série de termos ressonantes para esse ponto absoluto de orientação, “democracia-por-vir", “messianicidade” e assim por diante. É a questão de um horizonte de significado como a condição da agência moral da qual falei anteriormente. Meu ponto básico é que a desconstrução, quando entrou em cena pela primeira vez, deveria ter nos "libertado" - uso a palavra ironicamente -, pelo desmantelar de qualquer horizonte de significado. É por isso que entendo uma ruptura no pensamento de Derrida. Ao mesmo tempo, podemos ver porque o trabalho de desconstrução disruptivo e ilusório da sua fase anterior foi obrigado ou dirigido a algo mais construtivo e porque Derrida e seus acólitos estavam inclinados, como resultado, a ver apenas continuidade. Mas qual é a força desse dever ou direção? Até que ponto isso marca uma virada ou uma extensão? Se eu tivesse mais tempo, tentaria explicar como Schelling, nas décadas de 1830 e 1840, já estava tentando pensar sobre essas questões em seu relato da transição da filosofia "negativa" para a filosofia "positiva". Mas terei que desenvolver esse tema em outro lugar.

Como você avalia a relevância do idealismo alemão, especialmente dadas suas preocupações a respeito da filosofia de Schelling, para os debates contemporâneos na teoria social?

Eu disse anteriormente que, em certo ponto, meu interesse começou a se concentrar na relação entre os pensadores contemporâneos e o idealismo alemão. Derrida certamente se conecta ao idealismo alemão; ele sabe que está profundamente em dívida com Hegel, mas, como acabei de sugerir, acho que ele também está conectado com o pensamento pós-kantiano de maneiras que ele não percebe totalmente. No entanto, a maioria das pessoas interessadas em Derrida - Rodolphe Gasché é uma exceção notável - não tinha interesse em saber até que ponto seus problemas e questões eram assuntos já explorados intensamente na esteira de Kant. Eles não achavam que havia algo a aprender. No mundo de língua alemã, a grande exceção a essa regra foi Manfred Frank, que conhece muito bem os idealistas alemães e os românticos de Jena, para não mencionar Schleiermacher e a tradição hermenêutica. Manfred respondeu entusiasticamente, embora não sem reservas críticas, à filosofia francesa dos anos 1960 e escreveu em detalhes penetrantes sobre a rede de interconexões e correspondências ao pensamento pós-kantiano. A tradução em inglês 
de seu livro principal sobre o tema deveria ter tido um impacto muito maior, mas acho que o título What is Neostructuralism?, uma réplica direta do título alemão, deve ter confundido muitos leitores em potencial. ${ }^{16}$ No que diz respeito à Escola de Frankfurt, quase se poderia definir a Teoria Crítica de Frankfurt como o projeto de enriquecimento da tradição marxista, indo atrás de Marx para traçar todo o desenvolvimento de Kant a Hegel.

O idealismo alemão é um dos grandes períodos da história da filosofia europeia tout court, uma explosão de construção de sistemas, mas também de experimentação filosófica. De fato, o termo "idealismo", se não é exatamente um equívoco, pode ser enganoso para os não iniciados. Não há questão do mundo sendo construído na mente, a partir de experiências subjetivas ou qualquer coisa assim. 0 que tudo isso significa é que você não pode separar ser e normatividade - então, decididamente, isso os coloca em oposição às formas de pensamento mecanicista e determinista que, na modernidade, ameaçam constantemente invadir o mundo humano.

0 que é inovador nos idealistas alemães é que eles não estão apenas fazendo uma metafísica a-histórica, embora sua perspicácia filosófica seja incomparável, mas pensando de maneira autoconsciente sobre seu próprio tempo, sobre a modernidade e sobre os problemas fundamentais da modernidade. Apenas para dar poucos exemplos, eles perguntam: qual é a relação entre subjetividade humana e natureza? Esta é uma questão fundamental, que tem enormes consequências políticas e sociais no mundo contemporâneo, com as mudanças climáticas, a poluição e a destruição do meio ambiente. A questão da relação entre atividade humana, consciência humana e natureza é absolutamente central para o pensamento do idealismo alemão. Outro problema maior para eles é a relação entre moralidade, por um lado, e autorrealização, por outro. Novamente, esta é uma questão básica, não apenas em um sentido abstrato, mas como um conjunto de dilemas que todos nós enfrentamos ao viver nossas vidas. Já tocamos nisto em relação a Marcuse, a Adorno, à questão do impulso versus princípio, à noção de dessublimação repressiva e assim por diante. Qual é a relação entre a ideia moderna de encontrar a autorrealização e satisfação individuais como uma pessoa única e se comprometer com o que sabemos ser moralmente correto, com o que representa a justiça? É um erro pensar que, no fundo, deve sempre haver um conflito entre essas coisas? Se não, como determinamos nossas prioridades? Uma vez mais, qual é o papel da arte e d experiência estética no mundo moderno? A arte transfigura o mundo, nos reconciliando a ele ou, ao invés disso, perturba nossa consciência cotidiana e nos inspira a mudá-lo? A arte alcançou sua autonomia moderna, sua liberdade de estruturas preestabelecidas de significados, como a religião, ao custo de se degenerar em uma forma de jogo em última instância inconsequente? 0 idealismo alemão e, devo acrescentar, o romantismo filosófico de 16 Frank, M. (1989). What is Neostructuralism? Minneapolis: University of Minnesota Press. 
Jena intimamente ligado a ele, foram uma espécie de laboratório onde os pensadores estavam experimentando, experimentando diferentes possibilidades e respostas a essas questões básicas, que permanecem fundamentais hoje em dia.

Como você diferenciaria a filosofia da identidade entre Hegel e Schelling, tendo em vista o debate da não-identidade em Adorno?

Essa é uma questão muito complicada, então não tenho certeza se há respostas simples. Por um lado, os defensores de Hegel sempre dizem: "Hegel não está tentando reprimir a não-identidade. Hegel inclui diferença, incluir a não-identidade dentro de seu sistema é absolutamente fundamental para o seu modo de pensar. Assim, seria uma paródia sugerir que Hegel, em última análise, substitui a diferença ou a nãoidentidade". Por outro lado, o Schelling posterior chega à conclusão de que ainda existe um limite para o modo de pensar de Hegel. E se estamos falando de conexões entre Schelling e Adorno, em Schelling há também uma dimensão experimental, assim como uma dimensão dialética, que sustenta sua abordagem dessas questões.

Publiquei recentemente um artigo sobre esse aspecto de Schelling. Tratou do famoso tratado sobre a liberdade de 1809 e eu quis mostrar que, no Freiheitsschrift, Schelling tem um tipo de dupla metodologia; ele tem o que você pode chamar de uma metodologia "metadialética". ${ }^{17}$ Ele não nega de todo o imperativo racional de ajustar o conceito de liberdade em todo o nosso sistema de conceitos, mas também pensa que a liberdade é fundamentalmente evasiva, que ela resiste à articulação conceitual ou dialética. Portanto, há também uma dimensão fenomenológica irredutível ou dimensão experiencial da liberdade. No Freiheitsschrift, ele está tentando entender como essas duas formas de proceder se relacionam, a abordagem experiencial e a abordagem dialética ou conceitual. É assim que ele configura o problema na primeira página do texto.

Obviamente, ele está criando dificuldades para si mesmo, dizendo que a liberdade está tanto dentro quanto fora do sistema. Mas essa perspectiva dual é muito típica de seu modo de pensar. Mais tarde, a dimensão experiencial de sua filosofia foi apanhada por pensadores como Kierkegaard. Kierkegaard estava ouvindo o primeiro ciclo de palestras de Schelling em Berlim, em 1841-1842, e está claro que, apesar de sua rápida desilusão com a performance de Schelling, o aspecto "protoexistencialista" de Schelling alimentou seu próprio trabalho posterior. Mas esse é somente um aspecto para Schelling. Você não pode ter apenas o aspecto experiencial ou o aspecto fenomenológico, você também tem que ter o aspecto dialético, sistemático: você não pode focar simplesmente na existência humana e

17 Dews, P. (2017). Theory Construction and Existential Description in Schelling's Treatise on Freedom. British Journal for the History of Philosophy, 25(1), 2017; e Schelling, F. W. J. (2006). Philosophical Investigations into the Essence of Human Freedom. New York: State University of New York Press. 
deixar tudo o mais, natureza, história humana, na obscuridade, como os existencialistas posteriores tenderam a fazer. Há todo um mundo lá fora em que a liberdade tanto se encaixa quanto não se encaixa. Isso significa, então, que você deve tanto integrar quanto não integrar as duas dimensões. É o suficiente para deixá-lo louco, mas você pode ver como a abordagem de Schelling é ecoada na luta de Adorno com a questão da identidade, por exemplo quando ele afirma que "o não-idêntico [non-identical] é de fato idêntico - como ele mesmo mediado - e não idêntico [not identical], o outro contra todas as suas identificações" ${ }^{18}$. Na Dialética Negativa, Adorno afirma que esse é um insight hegeliano básico, que o próprio Hegel não conseguiu cumprir. Em minha opinião, é a posição que Schelling alcança, ao tentar enxergar além de Hegel.

Você poderia falar um pouco a respeito da crítica de Habermas a Hegel e do posicionamento em relação a Schelling?

Habermas publicou um longo ensaio sobre Schelling em 1963, em sua coleção de ensaios Teoria e Práxis. Ele estava em parte recorrendo a argumentos que já havia desenvolvido em sua tese doutoral, em 1954, dedicada a Schelling. ${ }^{19}$ Ele faz duas críticas básicas a Hegel no ensaio de 1963, uma das quais está preocupada com o caráter cíclico do sistema hegeliano. O próprio Hegel descreve seu sistema como um círculo de círculos e, em certo sentido, pode-se entender o que Hegel quer fazer, na medida em que pretende superar o problema das fundações, uma questão permanente na filosofia. Onde você inicia e como justifica o começo? Se você apresenta um sistema circular no qual o fim é também o começo e vice-versa, você parece não ter mais esse problema.

Mas Habermas se questiona então sobre como se entra no sistema pela primeira vez. Uma vez que você está dentro do sistema, tudo vai bem, mas como você ingressa, como começa? As pessoas geralmente não reconhecem o talento de Habermas para o aforismo, mas ele diz muito bem: "Systematisch ist ein Anfang des Systems nicht denkbar". Não há uma maneira sistemática de pensar o começo do sistema de Hegel. Isto se conecta claramente a Schelling, a respeito do que dissemos sobre o tipo de dimensão experiencial que deve se vincular a - sem ser redutível a dimensão sistemática ou dialética.

A outra crítica que ele então quer fazer é que mesmo que Hegel alegue totalmente confrontar sofrimento, medo e negatividade dentro de sua filosofia, se o sistema, se o modo de pensamento de Hegel, tem essa estrutura cíclica, então sofrimento, medo e negatividade tornam-se simplesmente um aspecto inevitável, repetitivo, da realidade. Voltando ao que estávamos discutindo anteriormente

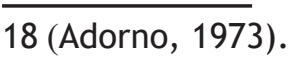

19 Habermas, J. (2004). "Dialectical Idealism in Transition to Materialism: Schelling's Idea of a Contraction of God and Its Consequences for the Philosophy of History". In: Norman, J. and Welchman, A. The New Schelling. London. 
sobre esperança e a dimensão utópica, soa como se Hegel houvesse eliminado esta dimensão, a aspiração por um futuro emancipado. Novamente, é uma crítica que Habermas deriva de Schelling. Schelling pensa que houve algum evento no passado da humanidade que nos colocou no caminho errado e produziu uma inversão, o que ele chama uma "falsa unidade", onde a base material particularista da existência humana domina sua dimensão espiritual. Habermas assume a visão de que Schelling deve estar certo contra Hegel a esse respeito - é isso que faz dele, ao invés de Hegel, o materialista proto-histórico, que é uma das principais afirmações do ensaio. Se quer ter esperança para o futuro ou uma esperança de emancipação, você deve ter um começo real do estado falso de coisas. Somente se houver uma base contingente do estado falso de coisas, pode haver alguma possibilidade de corrigir as coisas novamente.

Outro ponto de conexão com Adorno é que, como dissemos, ele apresenta algo como essa ideia na Dialética Negativa - diante da utopia, "dialética é a ontologia do estado falso de coisas". Em Adorno, a busca por um grau de controle humano sobre a natureza não é inerentemente ilegítima - pelo contrário, é racional. Mas Adorno retrata a dominação da natureza conduzindo à dominação social. Os dois parecem inseparáveis. Poderíamos questionar: "por quê? Por que os seres humanos não poderiam colaborar para dominar a natureza? Por que o domínio sobre a natureza produz divisão e dominação social?”. Parece-me que não há uma conexão necessária, inevitável entre esses dois aspectos da dominação. De fato, há pelo menos um momento na Dialética Negativa em que Adorno diz que deve ter havido algo comparável à Queda teológica, deve ter havido alguma catástrofe irracional no começo que colocou a humanidade em seu curso desastroso. É claro, uma vez que a dominação social começa, ela tem então seu próprio ímpeto, perpetua-se quase irresistivelmente

Este argumento forma parte da crítica de Adorno ao marxismo ortodoxo. Ele pensa que este está muito atrelado a Hegel, à ideia de um tipo de processo necessário, embora um que levaria à emancipação. Você pode considerar que não há nada inerentemente problemático em pensar que, embora a história humana seja uma sequência de estágios de dominação, opressão e sofrimento, se passarmos por esses estágios haverá um resultado positivo, emancipatório. Adorno resiste a essa maneira de pensar, mesmo que se possa dizer que é o modo de pensamento de Marx. Ele quer dizer: "Não, houve um começo contingente de dominação. Ela não teve que acontecer com necessidade inevitável”. Pode-se responder que essa é antes uma objeção moralmente motivada que uma objeção teórica. Há sem dúvida uma dimensão moral, mas acho que isso também se conecta ao pensamento de Schelling de que um processo necessário não pode produzir liberdade ou resultar em liberdade. Há um sentido em que a liberdade só pode ser seu próprio produto, só pode trazer a 
si mesma. Pode-se realmente considerar esta uma visão comum a todos os idealistas alemães, mas, do ponto de vista de Schelling, a circularidade do sistema de Hegel trai essa percepção. Levinas, que se conecta à Spätphilosophie de Schelling via Franz Rosenzweig, coloca a questão de forma sucinta: “Início e fim não são conceitos finais no mesmo sentido"20.

Para Schelling, a liberdade é como a tela em branco que é inscrita com a dialética necessária dos vetores do ser ou o que ele chama de Potenzen. Eles estão inscritos de tal forma que a própria tela quase desaparece. Essa liberdade primordial é o que ele anota como $A^{0}$, enquanto as potencialidades - contingência material, necessidade conceitual e suas resoluções - são notadas como $A^{1}, A^{2}$ e $A^{3}$. Isso me lembra as palestras de Adorno sobre História e Liberdade, nas quais ele argumenta - e novamente, esse é um tipo de ponto antimarxista - que a liberdade poderia ter irrompido a qualquer momento, por assim dizer²1. Adorno parece estar dizendo: "não quero a sua liberdade miserável ao fim da história, depois de termos passado por toda a dor e todo o sofrimento, pelos ciclos de dominação, como se aquela fosse uma espécie de recompensa”. Ele quer sugerir que há sempre uma possibilidade anárquica de liberdade, que a liberdade pode surgir a qualquer momento. Isso me lembra o $A^{0}$ de Schelling, a liberdade primordial sempre implícita em segundo plano como uma possibilidade, como a potencialidade das três dimensões da potencialidade.

Sobre a relação entre teoria e prática, como você avalia a representação de Lukács em relação a Adorno como alguém complacente no "Grande Hotel Abismo"?

Essa é uma questão bastante complicada. Adorno não era completamente um pensador da torre de marfim. Quando retornou à Alemanha depois da Segunda Guerra Mundial, ele deu muitas palestras no rádio, estava muito preocupado com o que ele chamou de educação para maturidade ou autonomia - a palavra alemã para ele, Mündigkeit, é difícil de ser traduzida para o inglês. Ele estava preocupado com a forma como o sistema educacional, o sistema escolar, poderia ser alterado a fim de aumentar a capacidade dos alunos de pensar por si mesmos e de pensar criticamente; e ele usou conceitos psicanalíticos para expor a dinâmica repressiva das formas existentes de pedagogia. De um modo paradoxal, ele era tanto utópico quanto reformista. Então não é bem verdade dizer que Adorno não tinha interesse na transformação social prática. Ao mesmo tempo, eu não gostaria de apenas defender Adorno. Sua meticulosidade, que poderia oscilar para a reação, pode facilmente se tornar cansativa. De certa forma, há algo muito mais atraente sobre o envolvimento positivo de Marcuse com os movimentos anti-imperialista e de protesto dos anos

20 Levinas, E. (1969). Totality and Infinity: An Essay on Exteriority. Pittsburgh: Duquesne University Press, p. 99. (Ed. port.: Levinas, E. (2008). Totalidade e Infinito. Lisboa: Ed. 70).

21 Adorno, T. (2006). History and Freedom: Lectures 1964-1965. Cambridge: Polity. 
1960, embora haja uma dolorosa ingenuidade em algo do que ele escreveu à época. Habermas uma vez me disse que achava esse lado político ativista de Marcuse muito agradável, eles foram bons amigos.

Você poderia falar um pouco sobre seus projetos neste momento?

Estou escrevendo um livro sobre a relação entre Schelling e Hegel. É principalmente sobre a filosofia tardia de Schelling e a crítica de Hegel que ele só começa a desenvolver totalmente após a morte de Hegel em 1831. Esta fase do trabalho de Schelling está ainda quase completamente desconhecida no mundo anglo-saxão, mesmo entre pessoas que se considerariam especialistas no idealismo alemão. Os textos em si não são exatamente fáceis - quase não há publicações, apenas as próprias conferências escritas de Schelling, algumas publicadas por seu filho nas Sämmtliche Werke e várias transcrições por assistentes; além disso, a argumentação é formidavelmente complexa e representa em certo sentido o engajamento retrospectivo de Schelling com todo o arco do idealismo alemão de Kant em diante, inclusive seu próprio papel juvenil em sua concepção e desenvolvimento. A preocupação central é aquela que temos abordado de diferentes direções desde o começo. Existe um limite para a razão? Há uma dimensão que escapa à razão? Em caso afirmativo, como se pode articular essa dimensão sem desistir da filosofia, sem ceder terreno à irracionalidade? Essas são algumas das questões filosóficas mais fundamentais que existem. Elas estão intimamente ligadas ao problema da liberdade, à questão de se a liberdade ela mesma é, em última análise, apenas a manifestação da razão, e é imensamente instrutivo observar as respostas divergentes que Hegel e Schelling dão [a tais questionamentos].

A nosso ver, há um tipo de integração entre seus estudos de Schelling neste momento e seus estudos anteriores do pós-estruturalismo. Em certo sentido, ambos estão preocupados com o problema do não-idêntico.

Adorno é central, acho difícil evitar voltar a ele. Ele estava imerso no idealismo alemão claro - e não apenas em Hegel -, mas também tinha uma espécie de sensibilidade pósestruturalista. "Não-identidade" é seu termo para essa dimensão do não conceitual e do não racional - em oposição ao irracional -, que não temos escolha a não ser nos abrir se quisermos ser completamente humanos. Ao contrário de alguns filósofos contemporâneos, não sou avesso a extrair da herança da metafísica ocidental para abordar essa dimensão, embora com o devido senso de historicidade - e tampouco Adorno foi [avesso]. Não posso fazer melhor do que concluir com aquela adorável frase da Dialética Negativa que citei anteriormente: “Experiência subjetivamente liberada e experiência metafísica convergem na humanidade”. 